\title{
CAVERNOUS HEMANGIOMA OF THE EARDRUM AND EXTERNAL AUDITORY CANAL: CASE PRESENTATION AND REVIEW OF LITERATURE
}

\author{
Anastasia Dimitriou ${ }^{1}$, Aristeidis Chrysovergis ${ }^{1}$, Dimitrios Giannopoulos ${ }^{2}$, Athanasios Bibas ${ }^{1}$ \\ ${ }^{1} 1^{\text {st }}$ Department of Otolaryngology, Hippokrateio Hospital, University of Athens, Athens, Greece \\ ${ }^{2}$ Department of Pathology, Hippokrateio Hospital, Athens, Greece
}

Corresponding author: Aristeidis Chrysovergis, MD, $1^{\text {st }}$ Department of Otolaryngology, Hippokrateio Hospital, University of Athens, 114 Vasilissis Sofias Ave, 11527 Athens, Greece, e-mail: achrysovergis@gmail.com

\begin{abstract}
Background: An external auditory canal cavernous hemangioma, with or without involvement of the eardrum and middle ear (ME), is rare; only 23 cases have been described so far.

Case report: We present a patient with cavernous hemangioma of the external auditory canal, which extended to the tympanic cavity and presented with intermittent episodes of bleeding. Total excision was curative with no recurrence at 9-month follow up. In addition, the literature is reviewed with respect to epidemiology, presentation, evaluation and treatment options for hemangiomas arising from the external ear canal.
\end{abstract}

Conclusions: Treatment is achieved by excising the entire lesion, using a transcanal, endaural, or postauricural approach. For hemangiomas extending to the medial aspect of the external auditory canal or the tympanic membrane, a retroauricular approach is favoured.

Key words: hemangioma $\bullet$ cavernous $\bullet$ external auditory canal $\bullet$ middle ear

\section{ANGIOMA CAVERNOSO DEL TÍMPANO Y DEL CONDUCTO AUDITIVO EXTERNO: DESCRIPCIÓN DEL CASO Y REVISIÓN DE LA LITERATURA}

Resumen

Introducción: Los angiomas cavernosos del conducto auditivo externo, con o sin ocupación de las estructuras del tímpano y del oído medio, son raros. Hasta hoy en día se han descrito sólo 23 casos.

Descripción del caso: Presentamos el caso del paciente con hemorragias periódicas del oído a consecuencia del angioma cavernoso del conducto auditivo externo que se extendía hacia la cavidad timpánica. La eliminación total de los cambios ha permitido curar al paciente. En el periodo de control de 9 meses no se han detectado síndromes de la recurrencia del cáncer. Además, el artículo proporciona una revisión de la literatura referente a la epidemiología, presentación clínica, evaluación y posibilidades terapéuticas de los angiomas cavernosos que se desarrollan en el conducto auditivo externo.

Conclusiones: El tratamiento de los susodichos cambios puede hacerse utilizando el acceso a través del conducto auditivo, acceso vía oído interno y por detrás de la oreja.

En el caso de los angiomas del conducto auditivo externo que se extienden hacia el tramo del oído medio es preferible el acceso detrás de la oreja.

Palabras clave: angioma cavernoso • conducto auditivo externo • oído medio

\section{КАВЕРНОЗНЫЕ АНГИОМЫ ПЕРЕПОНКИ И НАРУЖНОГО СЛУХОВОГО ПРОХОДА: ОПИСАНИЕ И ОБЗОР ЛИТЕРАТУРЫ}

\section{Изложение}

Введение: Кавернозные ангиомы наружного слухового прохода с или без распространения на структуру перепонки и среднего уха встречаются редко. До сих пор описано только 23 случая. 
Описание случая: Представим случай пациента с периодическими кровотечениями из уха при кавернозной ангиоме наружного слухового прохода, которая распространяется на перепонку. Полное удаление опухоли позволило ее излечить. В течение девяти-месячного контрольного периода признаков возобновления не зафиксировано. Кроме того, статья содержит обзор литературы, касающейся эпидемиологии, клинической картины, оценки и терапевтических возможностей при лечении кавернозной ангиомы наружного слухового прохода.

Итоги: Лечение вышеописанных изменений может происходить с использованием эндаурального, внутриушного и заушного подхода.

В случае ангиомы наружного слухового прохода, которая распространяется на среднее ухо, предпочитается заушный доступ.

Ключевые слова: кавернозные ангиомы • наружный слуховой проход • среднее ухо

\section{NACZYNIAKI JAMISTE BŁONY BĘBENKOWEJ I PRZEWODU SŁUCHOWEGO ZEWNĘTRZNEGO: OPIS PRZYPADKU ORAZ PRZEGLĄD LITERATURY}

\section{Streszczenie}

Wprowadzenie: Naczyniaki jamiste przewodu słuchowego zewnętrznego z lub bez zajęcia struktur błony bębenkowej i ucha środkowego są rzadkie. Jak doatąd opisnao tylko 23 przypadki.

Opis przypadku: Przedstawimy przypadek pacjenta z okresowymi krwawieniami z ucha w przebiegu naczyniaka jamistego przewodu słuchowego zewnętrznego rozszerzającego się na jamę bębenkową. Całkowite usunięcie zmiany pozwoliło na jego wyleczenie W 9-miesiecznym okresie kontrolnym nie odnotowano oznak wznowy. Ponadto, artykuł zawiera przegląd piśmiennictwa dotyczącego epidemiologii, obrazu klinicznego, oceny oraz możliwości terapeutycznych naczyniaków jamistych rozwijających się w przewodzie słuchowym zewnętrznym.

Wnioski: Leczenie opisanych wyżej zmian może odbywać się przez wykorzystanie dojścia przezprzewodowego, wewnątrzusznego i zausznego.

W przypadku naczyniaków przewodu słuchowego zewnętrznego rozszerzających się do ucha środkowego odcinka preferowany jest dostęp zauszny.

Słowa kluczowe: naczyniak jamisty • przewód słuchowy zewnętrzny • ucho środkowe

\section{Introduction}

Hemangiomas of the head and neck region are benign vascular lesions. Mulliken and Glowacki described in 1982 a classification of the vascular anomalies [1], and further subdivided hemangiomas into capillary or cavernous. Cavernous hemangiomas that involve the external auditory canal (EAC) and/or the tympanic cavity are rare, and they most frequently arise from the osseous EAC. The first two cases were reported by Freedman et al. (1972). According to our review of the current literature, 12 cases of cavernous hemangiomas confined to the EAC have been described. Tympanic hemangiomas usually arise from the lamina propria and only 4 cases confined to the eardrum cavernous hemangioma have been reported. Patients with ear canal hemangiomas are treated successfully with total excision of the lesion. Only two cases of recurrence have been reported $[2,3]$.

We present a patient with a vascular lesion arising from the EAC and extending to the eardrum and the tympanic cavity. The patient underwent excision of the lesion and the histological examination revealed a cavernous hemangioma. On a scheduled follow-up 9 months later there was no recurrence, as evidenced by a clinical examination and a follow-up CT scan.

\section{Case report}

A 52-year-old male was referred to our department with an 8-month history of painless mass and intermittent episodes of bleeding from his left external ear canal and hearing loss (Figure 1). No other symptoms were reported. Otoscopic examination revealed a soft, purple, exophytic mass, filling the left external ear canal, which was compressible and bled easily during otoscopy, obscuring the tympanic membrane (TM). The function of the CN VII was normal. The rest of the physical examination of head and neck, as well as the right ear, revealed no other symptoms.

A temporal bone CT scan demonstrated a mass of soft tissue $2.2 \times 1.7 \mathrm{~cm}$, filling the left external auditory canal. The ossicles were intact but the middle ear and mastoid air cells were filled with a soft tissue mass as well (Figure 2). On magnetic resonance imaging (MRI), both lesions showed hyperintensity on both T1- and T2-weighted images (the patient refused the use of contrast agent). There was no extension to either the ipsilateral temporomandibular joint or the parotid gland. The right ear was normal (Figure 3). 
Tone audiometry

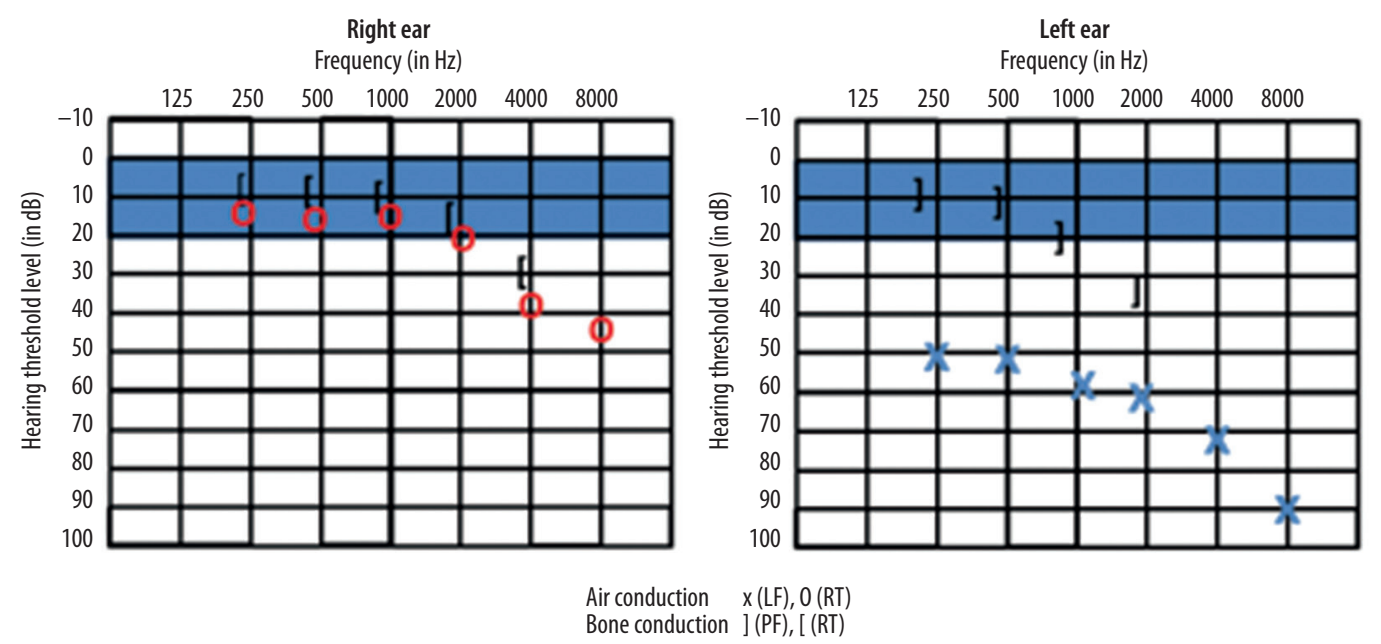

Figure 1. Preoperative audiogram

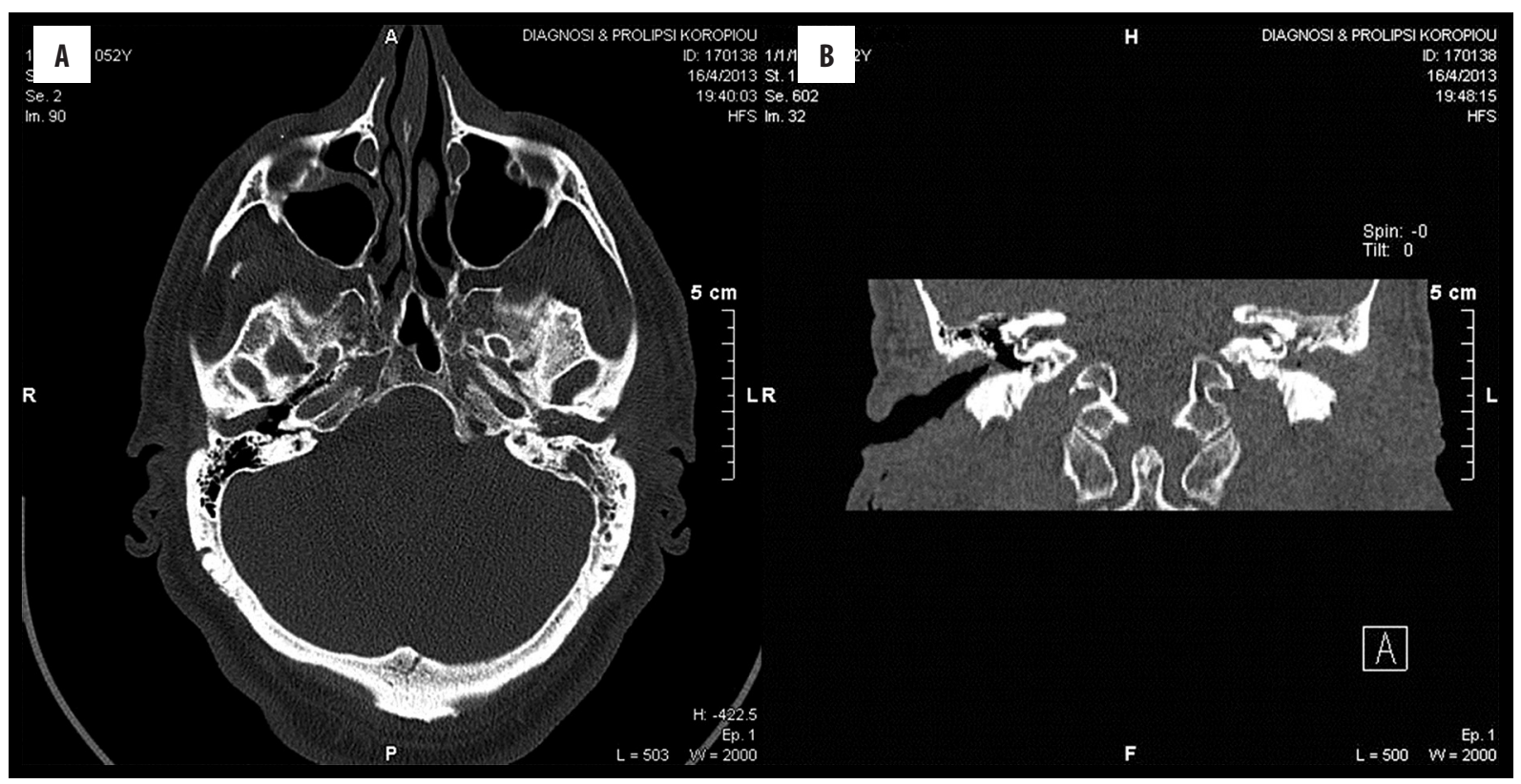

Figure 2. Computed tomography images of the lesion. (A) Axial CT image showing the left middle ear and mastoid air cells filled with a soft tissue mass. (B) Coronal view showing that the ossicular chain in the left ear is intact; the middle ear is filled with the mass

The patient underwent surgery under general anesthesia and the mass was completely excised via a postauricular approach. Although there was profound bleeding during surgery, this was controlled with bipolar diathermy. Following excision of the ear canal lesion, the mass was seen to be extending to the middle ear. A tympanomeatal flap was raised, and the intratympanic portion was fragmentally resected and removed. The tympanic membrane was reconstructed with an underlay temporalis fascia graft. The recovery of the patient was uneventful. The postoperative audiogram 8 months after surgery showed no conductive hearing loss.

Histologic examination in paraffin tissue sections with haematoxylin and eosin (H\&E) stain from tissue specimens of the external auditory canal revealed cavernous hemangioma, with large, thin-walled, blood-filled vascular spaces, with ulceration of the superficial squamous epithelium and moderate inflammatory infiltration of the neighbouring tissue. $H \& E$ sections of the middle ear specimens revealed a limited presence of the above-described hemangioma, with alterations of chronic otitis media and hemorrhagic infiltration of the surrounding tissues (Figures 4, 5). Nine months following surgery, there was no evidence of recurrence as evidenced by clinical examination and a postoperative CT scan (Figure 6).

\section{Discussion}

Hemangiomas consist of vascular tumors, which are benign lesions normally affecting the head and neck region; involvement of the external auditory canal, tympanic 


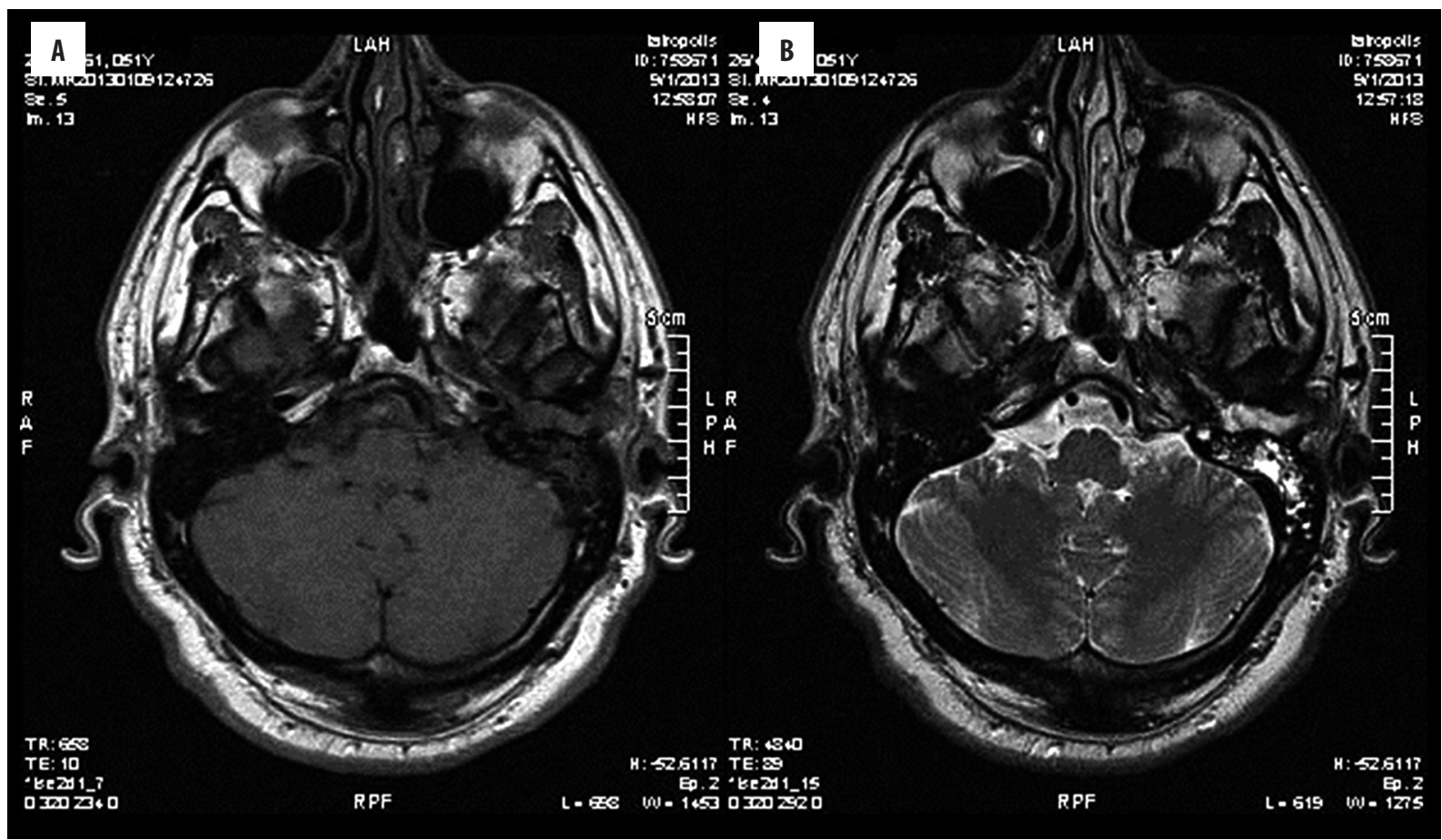

Figure 3. Axial, T1-weighted MRI (A, intermediate signal intensity) and T2-weighted image (B, high-signal intensity) showing lesion extending to the left middle ear. The right ear is normal

A

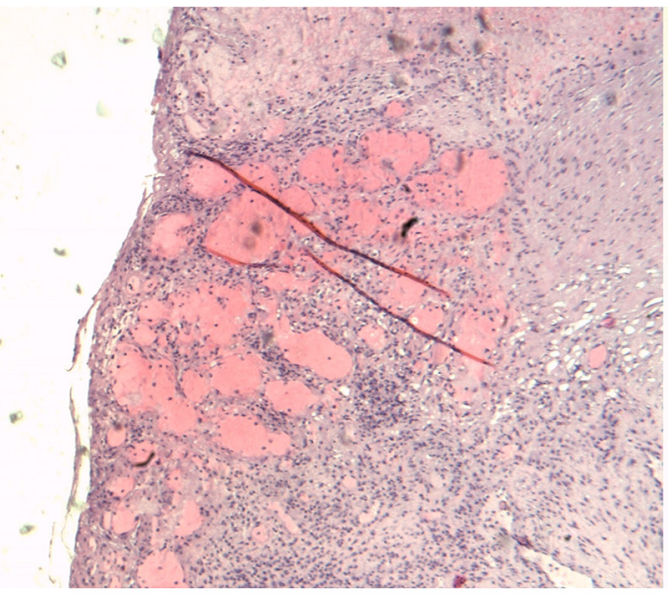

B

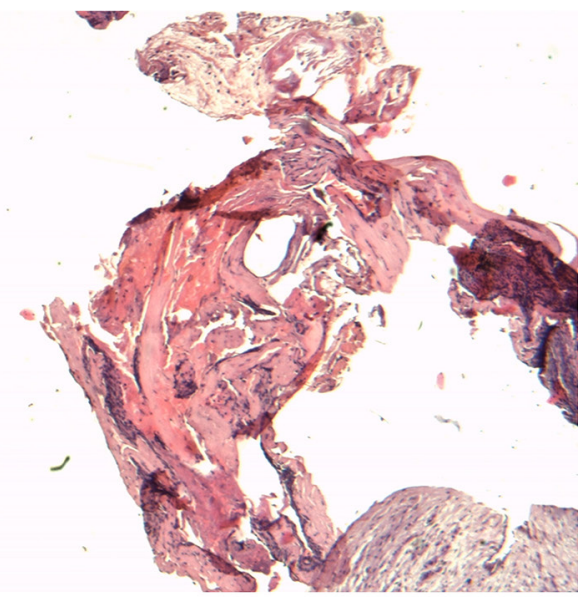

Figure 4. (A, B) Cavernous hemangioma in two tissue specimens (H\&E stain $\times 25)$ from external auditory canal, with large, thin-walled, blood-filled vascular spaces, partial ulceration of squamous epithelium, and moderate inflammatory infiltration in adjacent tissue

membrane, and tympanic cavity is extremely rare. Cavernous angiomas usually affect adult patients. The underlying pathophysiological mechanism remains unclear.

Hemangiomas of the external canal arise in its medial aspect, whereas tympanic hemangiomas arise from the lamina propria. Hemangiomatous lesions are divided into capillary and cavernous, with the latter being more common. There are 23 cases of cavernous, 8 cases of capillary, and 2 cases of mixed-type hemangiomas reported in the literature. Of the cavernous lesions that have been reported, 12 are limited to the EAC and only 4 cases to the TM (Table 1).

Presenting symptoms include otorrhea, tinnitus, headache, bleeding, aural fullness, and hearing loss. Occasionally they are found incidental to otoscopic examination. Diagnostic evaluation includes an otoscopic and a full head and neck physical examination, a pure tone audiogram, and imaging (temporal bone CT or MRI). The role of angiography in preoperative assessment is controversial. For extensive hemangiomas, it may be useful in identifying the feeding vessel in order to perform embolization preoperatively. Performing a temporal bone CT provides the ENT surgeon with valuable information about the exact size and extension of the hemangioma, as well as any possible bone erosion.

Each lesion of the external auditory canal should be differentiated from a number of other conditions, such as inflammatory aural polyp, glomus tumors, arteriovenous malformation, and EAC carcinoma. 


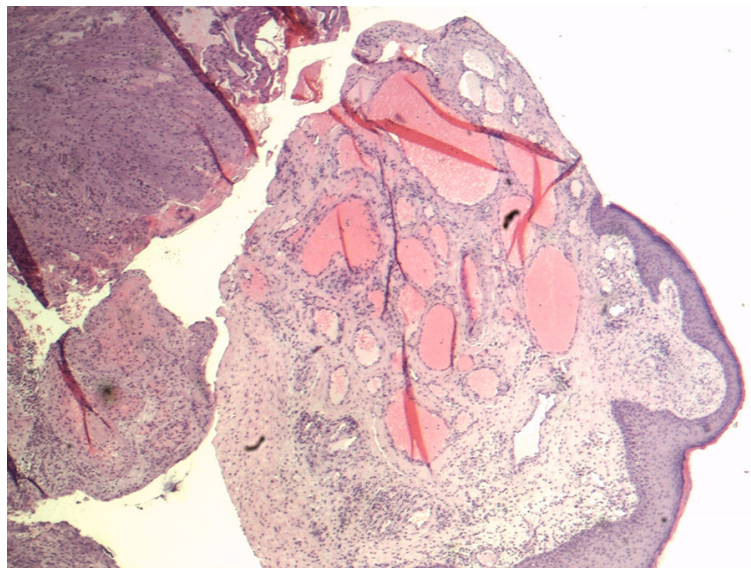

Figure 5. Cavernous hemangioma in tissue specimen from middle ear with minimal presence of hemangioma near small bone fragments $(H \& E$ stain $\times 40)$

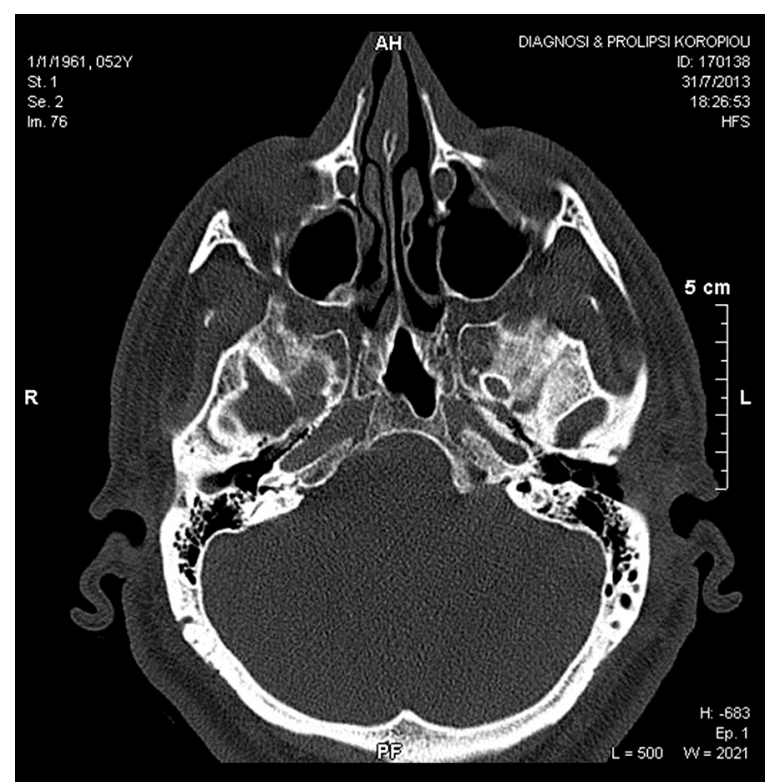

Figure 6. Postoperative axial CT image of the left middle ear cavity shows no evidence of recurrence

Table 1. Hemangiomas of the external auditory canal and/or tympanic membrane described in the literature

\begin{tabular}{|c|c|c|c|c|c|c|c|}
\hline & Author & $\begin{array}{l}\text { Age of } \\
\text { subject }\end{array}$ & Gender & Location & Symptoms & Histology & Management/approach \\
\hline 1 & $\begin{array}{l}\text { Freedman et al., } \\
1972\end{array}$ & 52 & M & $\mathrm{Eac} / \mathrm{Tm}$ & - & Cavernous & Endaural approach \\
\hline 2 & $\begin{array}{l}\text { Freedman et al., } \\
1972\end{array}$ & 57 & M & $\mathrm{Eac} / \mathrm{Tm}$ & Ear pain & Cavernous & Transcanal approach \\
\hline 3 & $\begin{array}{l}\text { Balkany et al., } \\
1978\end{array}$ & 63 & $\mathrm{~F}$ & $\mathrm{Tm}$ & - & Capillary & $\begin{array}{l}\text { 1.Observation } \\
\text { 2. Complete approach }\end{array}$ \\
\hline 4 & $\begin{array}{l}\text { Anrade et al., } \\
1983\end{array}$ & 59 & M & $\mathrm{Tm}$ & - & Cavernous & $\begin{array}{l}\text { Endaural approach } \\
\text {-tympanoplasty }\end{array}$ \\
\hline 5 & $\begin{array}{l}\text { Kemink et al., } \\
1983\end{array}$ & 52 & M & $\mathrm{Eac} / \mathrm{Tm}$ & - & Cavernous & $\begin{array}{l}\text { Tympanoplasty } \\
\text { - mastoidectomy }\end{array}$ \\
\hline 6 & $\begin{array}{l}\text { Hawke et al., } \\
1987\end{array}$ & 55 & M & Eac & $\begin{array}{l}\text { Blood-tinged } \\
\text { otorrhoea }\end{array}$ & Cavernous & Transcanal approach \\
\hline 7 & $\begin{array}{l}\text { Krueger et al., } \\
1988\end{array}$ & 50 & M & Eac & & Capillary & Transcanal approach \\
\hline 8 & $\begin{array}{l}\text { Jackson et al., } \\
1990\end{array}$ & 60 & $\mathrm{~F}$ & $\mathrm{Eac} / \mathrm{Tm} /$ Bone & $\begin{array}{l}\text { Hearing } \\
\text { impairment }\end{array}$ & Mixed & $\begin{array}{l}\text { 1. Elliptical excisional biopsy } \\
\text { 2. Partial temporal bone } \\
\text { resection, split thickness skin } \\
\text { graft }\end{array}$ \\
\hline 9 & $\begin{array}{l}\text { Magliuolo et al., } \\
1997\end{array}$ & 58 & $\mathrm{~F}$ & $\mathrm{Tm}$ & Tinnitus & Capillary & 15-month follow-up \\
\hline 10 & $\begin{array}{l}\text { Magliulo et al., } \\
2007\end{array}$ & 63 & M & $\begin{array}{l}\text { Eac/Tm/ } \\
\text { Middle ear }\end{array}$ & Pulsatile tinnitus & Cavernous & $\begin{array}{l}\text { Endaural approach } \\
\text {-tympanoplasty }\end{array}$ \\
\hline 11 & Joshi et al., 1999 & 16 & M & $\mathrm{Eac} / \mathrm{Tm}$ & $\begin{array}{l}\text { Discharge from } \\
\text { left ear, mass in } \\
\text { ear canal }\end{array}$ & Cavernous & Mastoidectomy \\
\hline 12 & $\begin{array}{l}\text { Yamakita et al., } \\
2000\end{array}$ & 59 & $\mathrm{~F}$ & Eac & - & Capillary & Excision \\
\hline 13 & $\begin{array}{l}\text { Bijelic et al., } \\
2001\end{array}$ & 78 & $\mathrm{~F}$ & $\mathrm{Tm}$ & - & Cavernous & $\begin{array}{l}\text { Transcanal approach } \\
\text {-tympanoplasty }\end{array}$ \\
\hline 14 & Limb et al., 2002 & 67 & $\mathrm{~F}$ & Eac & $\begin{array}{l}\text { Tinnitus, hearing } \\
\text { loss, fullness }\end{array}$ & Cavernous & $\begin{array}{l}\text { Endaural approach - split } \\
\text { thickness skin graft }\end{array}$ \\
\hline 15 & $\begin{array}{l}\text { Reeck et al., } \\
2002\end{array}$ & 53 & M & Eac & $\begin{array}{l}\text { Tinnitus, hearing } \\
\text { loss }\end{array}$ & Cavernous & Endaural approach \\
\hline
\end{tabular}




\begin{tabular}{|c|c|c|c|c|c|c|c|}
\hline & Author & $\begin{array}{l}\text { Age of } \\
\text { subject }\end{array}$ & Gender & Location & Symptoms & Histology & Management/approach \\
\hline 16 & Kazi et al., 2003 & 67 & $\mathrm{~F}$ & Eac & $\begin{array}{l}\text { Tinnitus, hearing } \\
\text { loss aural fullness }\end{array}$ & Cavernous & Endaural approach \\
\hline 17 & $\begin{array}{l}\text { Hiraumi et al., } \\
2005\end{array}$ & 51 & M & $\mathrm{Tm}$ & $\begin{array}{l}\text { Conductive } \\
\text { hearing loss, } \\
\text { otalgia, otorrhea }\end{array}$ & Capillary & Transcanal approach \\
\hline 18 & Yang et al., 2006 & 72 & $\mathrm{~F}$ & $\mathrm{Eac}$ & - & Cavernous & Transcanal approach \\
\hline 19 & $\begin{array}{l}\text { Verret et al., } \\
2007\end{array}$ & 31 & M & $\mathrm{Eac}$ & $\begin{array}{l}\text { Sensation of } \\
\text { foreign body, } \\
\text { hearing loss }\end{array}$ & $\begin{array}{l}\text { No } \\
\text { information }\end{array}$ & $\begin{array}{l}\text { Postauricular approach, } \\
\text { split thickness skin graft }\end{array}$ \\
\hline 20 & $\begin{array}{l}\text { Covelli et al., } \\
2008\end{array}$ & 45 & $\mathrm{~F}$ & $\mathrm{Eac}$ & - & Cavernous & Endaural approach \\
\hline 21 & Yeo et al., 2008 & 49 & $\mathrm{~F}$ & $\mathrm{Tm}$ & $\begin{array}{l}\text { Hearing loss, } \\
\text { intermittent } \\
\text { otorrhagia }\end{array}$ & $\begin{array}{l}\text { No } \\
\text { information }\end{array}$ & Observation \\
\hline 22 & $\begin{array}{l}\text { Yasar et al., } \\
2009\end{array}$ & 32 & $\mathrm{~F}$ & $\mathrm{Eac}$ & $\begin{array}{l}\text { Intermittent } \\
\text { otorrhagia }\end{array}$ & Capillary & Transcanal approach \\
\hline 23 & $\begin{array}{l}\text { Rutherford } \\
\text { et al., } 2010\end{array}$ & 62 & $\mathrm{~F}$ & $\mathrm{Eac}$ & $\begin{array}{l}\text { Bleeding, aural } \\
\text { pressure }\end{array}$ & Cavernous & $\begin{array}{l}\text { 1. Endaural excision } \\
\text { 2. Trans-canal excision, TMJ } \\
\text { arthrotomy, preoperative } \\
\text { embolization }\end{array}$ \\
\hline 24 & Wu et al., 2010 & 36 & $\mathrm{~F}$ & $\mathrm{Eac} / \mathrm{Tm}$ & $\begin{array}{l}\text { Hearing } \\
\text { impairment, aural } \\
\text { fullness, otorrhea }\end{array}$ & Capillary & Excision - myringoplasty \\
\hline 25 & $\begin{array}{l}\text { Bovo et al., } \\
2010\end{array}$ & 54 & M & $\begin{array}{l}\text { Eac/Middle } \\
\text { ear/Post- } \\
\text { auricular } \\
\text { sulcus }\end{array}$ & $\begin{array}{l}\text { Non-pulsating } \\
\text { tinnitus, mild } \\
\text { hearing loss, } \\
\text { aural fullness, } \\
\text { retroauricular } \\
\text { swelling }\end{array}$ & Cavernous & $\begin{array}{l}\text { Postauricular approach, canal } \\
\text { wall up mastoidectomy, } \\
\text { tympanoplasty }\end{array}$ \\
\hline 26 & $\begin{array}{l}\text { Spector et al., } \\
2011\end{array}$ & 59 & $\mathrm{~F}$ & $\mathrm{Tm}$ & $\begin{array}{l}\text { Hearing loss, non- } \\
\text { pulsatile tinnitus }\end{array}$ & Capillary & Excisional biopsy \\
\hline 27 & Jang et al., 2011 & 49 & M & $\mathrm{Tm}$ & Pulsatile tinnitus & Cavernous & $\begin{array}{l}\text { Postauricular approach } \\
\text {-tympanoplasty }\end{array}$ \\
\hline 28 & Martines, 2012 & 59 & M & $\mathrm{Eac}$ & $\begin{array}{l}\text { Bleeding, aural } \\
\text { pressure, tinnitus, } \\
\text { hearing loss }\end{array}$ & Cavernous & Endaural approach \\
\hline 29 & $\begin{array}{l}\text { Mevio et al., } \\
2012\end{array}$ & 55 & M & $\mathrm{Tm}$ & $\begin{array}{l}\text { Ear pain, hearing } \\
\text { impairment, } \\
\text { pulsatile tinnitus }\end{array}$ & Cavernous & Transcanal approach \\
\hline 30 & $\begin{array}{l}\text { Vlaski et al., } \\
2012\end{array}$ & 38 & $\mathrm{~F}$ & $\mathrm{Eac}$ & $\begin{array}{l}\text { Clogged ear, } \\
\text { pain, right-sided } \\
\text { occipital headache }\end{array}$ & Cavernous & Transcanal approach \\
\hline 31 & $\begin{array}{l}\text { Vlaski et al., } \\
2012\end{array}$ & 68 & $\mathrm{~F}$ & $\mathrm{Eac}$ & $\begin{array}{l}\text { Intermittent } \\
\text { blood-tinged } \\
\text { discharge, } \\
\text { otorrhagia, } \\
\text { impaired hearing, } \\
\text { headaches }\end{array}$ & Mixed & $\begin{array}{l}\text { Postauricular approach } \\
\text {-myringoplasty }\end{array}$ \\
\hline 32 & Shu et al., 2013 & 57 & $\mathrm{~F}$ & $\mathrm{Eac}$ & Ear pain & Cavernous & Postauricular approach \\
\hline 33 & Feng et al., 2013 & 50 & $\mathrm{~F}$ & $\mathrm{Eac}$ & $\begin{array}{l}\text { Echo inside the } \\
\text { left ear }\end{array}$ & Cavernous & Endaural approach \\
\hline 34 & Feng et al., 2013 & 88 & M & $\mathrm{Eac}$ & No symptoms & Cavernous & $\begin{array}{l}\text { Excision under local } \\
\text { anaesthesia }\end{array}$ \\
\hline 35 & $\begin{array}{l}\text { Dimitriou et al., } \\
2015 \\
\text { (this study) }\end{array}$ & 52 & M & $\begin{array}{l}\text { Eac/Tm/ } \\
\text { Middle ear }\end{array}$ & Bleeding & Cavernous & $\begin{array}{l}\text { Postauricular approach } \\
\text {-tympanoplasty }\end{array}$ \\
\hline
\end{tabular}

M - male; F - female; Eac - external auditory canal; Tm - tympanic membrane. 
Treatment of choice is complete excision of the lesion under general anaesthesia, although the "watch and wait" method has been described in the literature for small, asymptomatic hemangiomas [4]. The lesion may be excised through a transcanal, endaural, or postauricular approach. The extent of the hemangioma is decisive in choosing the most appropriate surgical approach. Small hemangiomas located on the external auditory canal can be extracted via a transcanal or endaural incision [7-7]. More extended lesions in which the middle ear is involved require a postauricular approach with subsequent tympanoplasty, with or without mastoidectomy $[8,9]$. For hemangiomas involving only the tympanic membrane, the removal of the external layer of the eardrum is considered adequate [10]. In our case an endaural approach was initially used, but visualization and access of the most medial part of the tumor was poor due to excessive bleeding. We therefore used an additional postauricular incision, which allowed us better access and easier management of the perioperative bleeding. We therefore feel that a postauricular approach allows better access in cases where the tumor involves the medial aspect of the osseous EAC or TM.
Only a few authors propose the use of preoperative angiography in selected cases to identify the feeding vessel and either embolize it at this stage or ligate it intraoperatively, although this is not commonly performed [2]. If the surgical excision is complete, the likelihood of recurrence appears to be small. Two cases of recurrence have been described in the literature. Jackson (1990) managed one such case with partial temporal bone resection [3] while Rutherford and colleagues [2] performed a transcanal excision in conjunction with temporomandibular joint arthrotomy. There was no further recurrence in either case.

\section{Conclusions}

Hemangiomatous lesions of the external ear canal are rare. The imaging modality of choice is high resolution CT of the temporal bone. Angiography is not used as a routine, except in cases where extensive intraoperative bleeding is expected. Office-based biopsy of those lesions is not usually recommended. Treatment of choice is the complete surgical excision, with a transcanal, endaural, or retroauricular approach, depending on the extent of the mass. A postauricular approach is favoured in cases of extension to the medial aspect of the EAC and/or the TM.

\section{References:}

1. Mulliken JB, Glowacki J. Hemangiomas and vascular malformations in infants and children: A classification based on endothelial characteristics. Plast Reconstr Surg, 1982; 69: 412-22.

2. Rutherford KD, Leonard G. Hemangiomas of the external auditory canal. Am J Otolaryngol, 2010; 31: 384-86.

3. Jackson CG, Levine SC, McKennan KX. Recurrent hemangioma of the external auditory canal. Am J Otol, 1990; 11: 117-18.

4. Yeo A, Majithia A, Kalan A. Haemangioma or vascular malformation of the tympanic membrane? A case report and review of literature. Indian J Otolaryngol Head Neck Surg, 2008; 60: 59-61.

5. Magliulo G, Parrotto D, Sardella B, Della Rocca C, Re M. Cavernous hemangioma of the tympanic membrane and external ear canal. Am J Otolaryngol, 2007; 28(3): 180-83.
6. Vlaški L, Dankuc D, Vučković N, Kljajić V, Dragičević D, Lemajić-Komazec S. Hemangiomas of the external auditory canal: A literature review and two new case reports. Cent Eur J Med, 2012; 7(3): 344-48.

7. Martines F, Bentivegna D, Maira E, Marasà S, Ferrara S. Cavernous haemangioma of the external auditory canal: Clinical case and review of the literature. Acta Otorhinolaryngol Italica, 2012; 32: 54-57.

8. Bovo R, Ciorba A, Castiglione A, Martini A. Cavernous hemangioma of the external ear: case report and literature review. B-ENT, 2010; 6: 127-30.

9. Jang $\mathrm{CH}$, Choi HS, Hong YS, Cho YB. Cavernous hemangioma of the tympanic membrane. Clin Exp Otorhinolaryngol, 2011; 4: 109-11.

10. Mevio E, Cazzaniga M, Mullace M, Paolotti D. Hemangioma of the tympanic membrane: A case and a review of the literature. Case Rep Otolaryngol, 2012; 2012: 402630 